\title{
Effect of termite activity on soil chemical properties using baiting systems at an arboretum area in Pontianak, West Kalimantan, Indonesia
}

\author{
YULIATI INDRAYANI", RAHMAWATI USWATUN KHASANAH, SOFWAN ANWARI \\ Faculty of Forestry, Universitas Tanjungpura. Jl. Prof. Hadari Nawawi, Pontianak 78121, West Kalimantan, Indonesia. Tel.: +62-561-765342, 583865 \\ vemail: mandaupermai@yahoo.com
}

Manuscript received: 7 November 2021. Revision accepted: 30 March 2021.

\begin{abstract}
Indrayani Y, Khasanah RU, Anwari S. 2021. Effect of termite activity on soil chemical properties using baiting systems at an arboretum area in Pontianak, West Kalimantan, Indonesia. Biodiversitas 22: 2125-2130. Termites play an essential and positive role as decomposers in nature, apart from being known as wood-destroying insects. These two varying characteristics led to the development of termite control technology, capable of digesting cellulose components and making soils rich in organic compounds. Therefore, this study examines the soil's biogenic structure due to termite activity using a control technology with a baiting system. The bait was made with various compositions of eucalyptus leaves, paper and cardboard, 60\%: 40\%: 0\%, 60\%: 20\%: 20\%, 60\%: 0\%: 40\%, 0\%: 100\%: 0\% and 0\%: $0 \%: 100 \%$ with a size of $2 \mathrm{~cm} \times 2 \mathrm{~cm} \times 1 \mathrm{~cm}$ and eucalyptus leaves as an attractant. In addition, a PVC tube measuring $10 \mathrm{~cm}$ diameter and $20 \mathrm{~cm}$ height with 25 holes consisting of $3 \mathrm{~mm}$ diameter on the side was used for field application. A total of 100 grams of bait for each composition was entered into the feed tube and placed in the Arboretum of Tanjungpura University, West Kalimantan, Indonesiawith three replications and left for 21 days. At the end of the observation period, the soil's biogenic structures with termites were analyzed to determine their chemical properties. Furthermore, the same analysis was also carried out on the soil surrounding the test area without termite activity for comparison. The results showed that the $\mathrm{pH}, \mathrm{C} / \mathrm{N}$ ratio, C-Organic, Nitrogen, Phosphorus, and Potassium contents as well as Cation Exchange Capacity of the soil produced from the tube containing the bait with a composition of 60\%: 0\%: $40 \%$ was significantly higher. This means that the soil's biogenic structure produced by termite activity with a baiting system increases land productivity and chemical properties.
\end{abstract}

Keywords: Baiting system, organic waste, soil chemical properties, subterranean termites, termite control

\section{INTRODUCTION}

In tropical areas, termites are known as insects that destroy wooden structures (Perace 1997), as well as agricultural and plantation crops (Darlington 1987; Apori et al. 2020b). However, termites also play an important role in natural ecosystems (Darlington and Dransfiled 1987; Black and Okwakol 1997). The level of soil fertility is caused by several factors, such as soil macrofauna, which determines the land productivity of plant growth. One of the macrofauna affecting the soil's physical, chemical, and biological characteristics is termites (Apori et al. 2020b).

Several studies have been carried out to determine the physical and chemical properties of termite nests. $\mathrm{Li}$ et al. (2017) reported the effect of termites on soil $\mathrm{pH}$, while Afolabi et al. (2014) analyzed the chemical elements, such as organic carbon, total nitrogen, and phosphorus availability. Furthermore, Apori et al. (2020b) researched the chemical content of organic carbon, availability of phosphorus, total nitrogen, potassium, and magnesium $\left(\mathrm{Mg}^{2+}\right)$ contained in termite nests. Deke et al. (2016) also reported the chemical content of the soil in termite nests in the form of total nitrogen, with the availability of phosphorus and exchangeable cations and CEC. Although the soil chemical compounds reported in these studies were derived from termite nests, no research has been conducted to determine their activity in increasing soil chemical compounds outside their nest. Therefore, it is necessary to observe the termites' activity in increasing soil chemical compounds outside their nests to determine their role in enhancing land productivity.

The technique used to collect soil from termite activity can be carried out using a baiting system. Indrayani et al. (2016) carried out research on collecting soil from termite activity using a baiting system made from newspaper with soybean boiled water as a nutritional enhancement. The research indicated an increase in bulk density, organic carbon, and $\mathrm{C} / \mathrm{N}$ ratio in the soil. Indrayani et al. (2018) further improved the bait composition by adding natural attractants to attract termites, which were tested on a laboratory scale. However, bait application using this natural attractant has not been tested on a field scale. Therefore, this study determines the soil's chemical characteristics from termite activity through the baiting system from organic waste in the Arboretum of Tanjungpura University, West Kalimantan, Indonesia. Termites are expected to walk into the tube, eat the bait, and produce biogenic products capable of improving the soil's chemical properties. The results are expected to act as an essential part of providing necessary information regarding termite management. 


\section{MATERIALS AND METHODS}

\section{Study area}

This study was carried out at the Arboretum area of Tanjungpura University, Pontianak, West Kalimantan, as shown in Figure 1. The geographic location is $0^{\circ} 03^{\prime} 07^{\prime \prime}$ $0^{\circ} 03^{\prime} 0{ }^{\prime \prime} \mathrm{S}$ latitude and $109^{\circ} 20^{\prime} 58^{\prime \prime}-109^{\circ} 21^{\prime} 07^{\prime \prime} \mathrm{E}$ longitude. The soil types used in the study area were organosol, gley, humus, and alluvial. Furthermore, the average rainfall, temperature, and humidity were $3000-4000 \mathrm{~mm}$ per year, 26.1- $27.4^{\circ} \mathrm{C}$, and $86-92 \%$, with a study height of 0.10 to $1.5 \mathrm{~m}$ above sea level (Development Planning Agency at Sub-National Level (BAPEDA) of Pontianak City 2018).

\section{Procedures}

\section{Material preparation}

This research was carried out using the old and young eucalyptus leaves. The leaves were air-dried for 5 days, then mashed using a hammer mill and filtered with a mesh size of 20. The middle part of the corrugated cardboard and paper was used to carry out this research. Furthermore, the paper and cardboard are cut or torn in small sizes, then dried under the sun for 24 hours before being mashed using a hammer mill and sieved with a mesh size of 20 .

\section{Bait making process}

Paper and cardboard were soaked in distilled water for 20 minutes to make it easier to mix the material between the paper and eucalyptus leaf powder. Furthermore, the paper was squeezed using a croton cloth and mixed with mashed eucalyptus leaves before the bait was molded using a $2 \mathrm{~cm} \times 2 \mathrm{~cm} \times 1 \mathrm{~cm}$ zinc. The bait was made with various compositions of eucalyptus leaves, paper and cardboard, namely 60\%: 40\%: 0\%, 60\%: 20\%: 20\%, 60\%: $0 \%$ : $40 \%$, 0\%: $100 \%: 0 \%$ and $0 \%: 0 \%: 100 \%$.

The field test was carried out by inserting 100 grams of bait into a PVC pipe measuring $10.16 \mathrm{~cm}$ in diameter and a height of $20 \mathrm{~cm}$. On the side of the tube, 25 holes were made with a diameter of $0.3 \mathrm{~cm}$. Furthermore, $\mathrm{PVC}$ pipes or bait tubes are planted to a depth of $20 \mathrm{~cm}$ in the Arboretum of Tanjungpura University, Pontianak, Indonesia in areas with high termite attack activity, which was determined based on its presence under the litter or the nests found on the ground. The bait tube was randomly placed for each different composition and repeated three times. The test unit was left in the field for up to 21 days to allow termites to attack the bait. The soil in the tube caused by termite's activities was separated from the bait carefully then analyzing at the Laboratory of Chemistry and Soil Fertility, Tanjungpura University, to measure the organic $\mathrm{C}$ content, nitrogen, phosphorus, $\mathrm{pH}$, and cation exchange capacity (CEC).
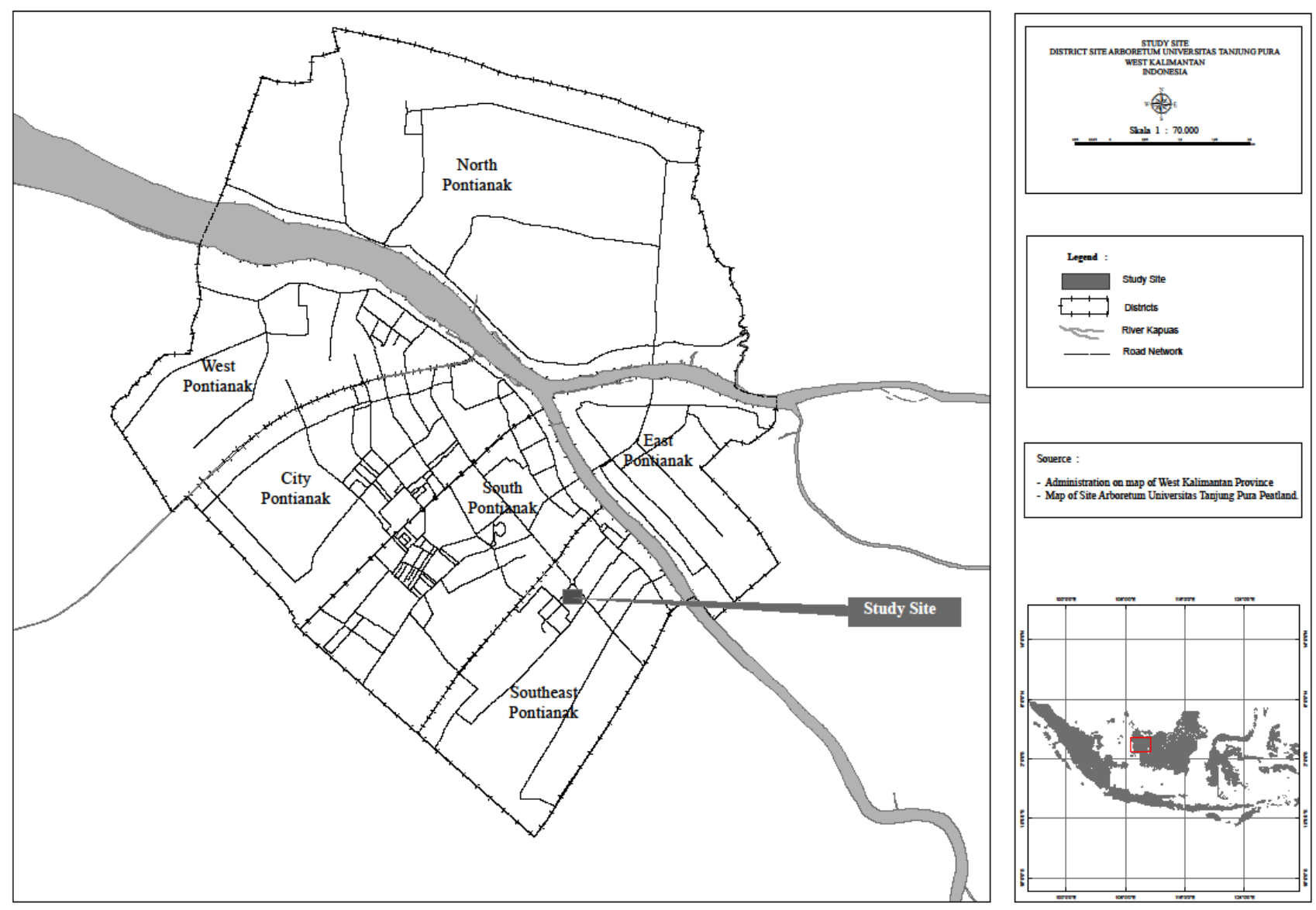

Figure 1. Map of the study area in Arboretum Tanjungpura University, West Kalimantan Province, Indonesia. Source: Administrative Boundary Map (2003) 
Field testing and soil analysis

Organic $\mathrm{C}, \mathrm{N}$, and $\mathrm{P}$ were measured by using Spectrophotometer (Rayleigh UV - 1800). C-organic and $\mathrm{N}$ content were determined from a $0.5 \mathrm{~g}$ air-dry soil sample, while an amount of $2.5 \mathrm{~g}$ air-dry soil sample was used for $\mathrm{K}$ and $\mathrm{P}$ content quantified. Soil $\mathrm{pH}$ was determined from a $10 \mathrm{~g}$ of soil sample placed into a beaker with distilled water until $50 \mathrm{ml}$ then stirred for 30 minutes, and measured with calibrated $\mathrm{pH}$ meter. The soil sample from surrounding the test unit within $1 \mathrm{~m}$ was taken using a soil ring measuring $5 \mathrm{~cm}$ in diameter as a control.

\section{Data analysis}

Data were statistically analyzed by Variable Analysis with factorial design by Dunnett's test, and Tukey's Analysis was used to compare the mean values.

\section{RESULTS AND DISCUSSION}

\section{Soil acidity (pH)}

Bait made of cardboard significantly increased soil $\mathrm{pH}$ (Tukey's test: $\mathrm{P}<0.01$ ) and significantly different than bait containing eucalyptus leaves and paper nor paper only and soil control (Tukey's test: $\mathrm{P}<0.01$ ) (Figure 1). According to Buckman and Brady (1960), several essential nutrients are closely related to soil $\mathrm{pH}$, leading to a rise in absorbed nutrients. Low soil $\mathrm{pH}$ causes plants to be unable to utilize $\mathrm{N}, \mathrm{P}, \mathrm{K}$, and other nutrients needed. It also leads to the availability of toxic elements such as aluminum, which poison plants and binds $\mathrm{P}$, thereby making it impossible to absorb plants (Hardjowigeno 2007). There is a significant difference in the soil $\mathrm{pH}$ value between the soil collected in the bait tube from termite activity and the surrounding (Figure 1).

These results are in line with the studies carried out by Li et al. (2017) and Deke et al. (2016), which stated that termite nests' soil $\mathrm{pH}$ is higher than the surrounding. The bait compositions showed that those containing eucalyptus leaves and cardboard led to a higher soil $\mathrm{pH}$ compared to containing paper only nor paper and eucalyptus. This finding is supported by the research carried out by Indrayani et al. (2017b, 2018), which stated eucalyptus leaf extract can be used as an attractant for termites.

\section{Organic carbon $(C)$ content}

The soil organic $\mathrm{C}$ content in the tube containing the bait made of cardboard and eucalyptus leaves was significantly higher (Tukey's test: $\mathrm{P}<0.01$ ) compare to the surrounding soil and the bait made from paper (Figure 2).

Figure 2 proves that eucalyptus leaves have attractive properties that attract termites to the bait (Indrayani et al. 2017, 2018; Noviansari et al. 2013). The difference in the amount of cellulose content in cardboard is $75 \%$ (Yanez et al. 2004), while $64.85 \%$ of paper is found in the dry weight (Sholikhah et al. 2018). The cellulose content in paper also makes termites more interested in eating the bait. Muin and Arif (2017) confirmed this analysis by stating that a mixture of degraded pine wood with paper, cardboard and newsprint are formulated into attractive baits for termites.
The high organic C content of termite nesting from the surrounding soil was also reported by Lavelle et al. (1997), Afolabi et al. (2014), and Apori et al. (2020a).

\section{Soil nitrogen $(\mathbf{N})$}

The total nitrogen content plays an essential role in improving soil chemistry. According to Sudaryono (2009), nitrogen is used to improve vegetative plant growth. The soil collected from the bait tube contains bait made of eucalyptus leaves and cardboard with the composition of 60:40 show a significantly higher content of total nitrogen and significantly different than the surrounding soil and other bait with other compositions (Tukey's test: $\mathrm{P}<0.05$ ), as shown in Figure 3. The rest bait with other compositions, as shown in Figure 3, were not significantly different at Tukey's test: $\mathrm{P}<0.05$.

An increase in the total amount of nitrogen was recorded in eucalyptus leaf bait and cardboard with the composition of 60:40 compared to the surrounding soil and other composition. The high value of total nitrogen in the bait containing eucalyptus leaves and cardboard (60:40) proves that subterranean termites prefer this composition. This phenomenon is understandable because the total nitrogen content in termite nests is higher than the surrounding soil (Jouquet et al. 2018; Apori et al. 2020b; Afolabi et al. 2014).

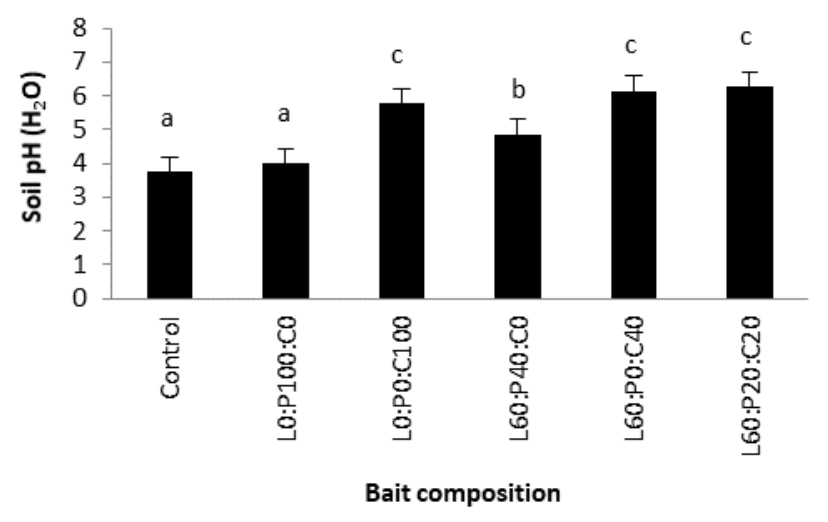

Figure 1. Soil acidity $\left(\mathrm{pH} \mathrm{H}_{2} \mathrm{O}\right)$ at various bait compositions. L: leaf; P: paper; C: cardboard. Columns with different letters differ significantly at a $99 \%$ confidence level.

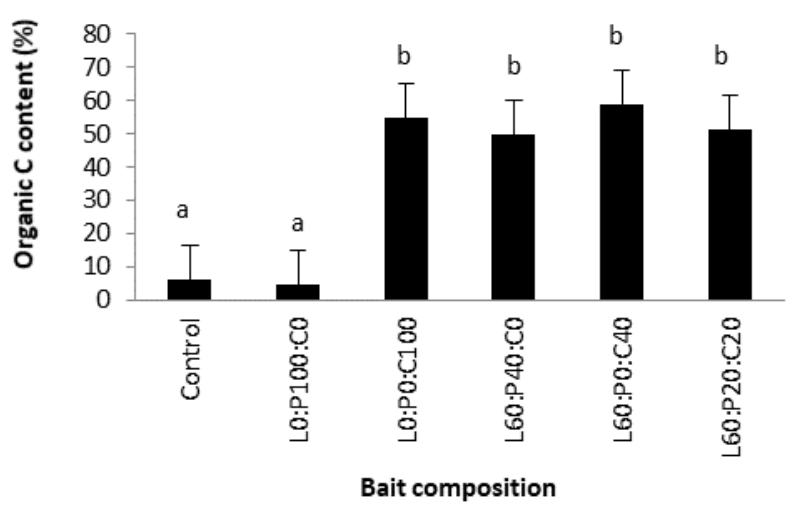

Figure 2. Soil organic C content (\%) at various bait compositions. Caption see in Figure 1. Columns with a different letter differ significantly at a $99 \%$ confidence level 


\section{C/N ratio}

The $\mathrm{C} / \mathrm{N}$ ratio is the ratio between the amounts of elemental carbon $(\mathrm{C})$ content to the nitrogen $(\mathrm{N})$ contained in organic material (Priya et al. 2017). The decrease in nitrogen content increased the $\mathrm{C} / \mathrm{N}$ ratio in the study area. Furthermore, the $\mathrm{C} / \mathrm{N}$ concentration ratio was significantly higher in the bait tube's soil with a $100 \%$ cardboard composition and showed significantly different than other compositions (Tukey's test: $\mathrm{P}<0.01$ ) (Figure 4.)

The $\mathrm{C} / \mathrm{N}$ ratio of the surrounding soil and the bait made of $100 \%$ paper is low, at 8.05 and 5.21, and significantly different from other bait compositions (Tukey's test: P $<0.01$ ). This is because the bait made of $100 \%$ paper does not contain eucalyptus leaves which can attract termites came to the bait (Indrayani et al. 2016). In this research, bait without cardboard resulting in a low $\mathrm{C} / \mathrm{N}$ ratio and $\mathrm{C}$ organic content. This is in line with Muin et al. (2015), who found higher termite attract in bait with cardboard than bait without cardboard. According to Syahfitri (2008), organic matter cannot be used directly by plants because the $\mathrm{C} / \mathrm{N}$ ratio does not match those in the soil, ranging from 10-12. However, when the organic matter has a $\mathrm{C} / \mathrm{N}$ ratio close or equal to those in soil, plants can use the material. The $\mathrm{C} / \mathrm{N}$ ratio of the soil collected in the bait tube in this study was high due to several factors, such as climate. According to Buckman and Brady (1960), temperature and rainfall significantly affect the soil's $\mathrm{C} / \mathrm{N}$ content at the time of data collection. Conversely, the research carried out by Bera et al. (2020) in West Bengal, India, stated that the $\mathrm{C} / \mathrm{N}$ ratio value in termite nests is smaller than the surrounding soil.

\section{Available phosphorus (P)}

The average value of $\mathrm{P}$ availability $\left(\mathrm{P}_{2} \mathrm{O}_{5}\right)$ is shown in Figure 5. The use of $100 \%$ cardboard and the addition of eucalyptus leaves to cardboard in the making bait increases the $\mathrm{P}$ availability. However, the $\mathrm{P}$ concentration in the bait with the addition of eucalyptus leaves on cardboard is significantly higher than ambient soil and other compositions (Tukey's test: $\mathrm{P}<0.01$ ), as shown in Figure 5.

In general, the $\mathrm{P}$ soil in the bait tube was significantly higher than the surrounding (Tukey's test: $\mathrm{P}<0.01$ ). The $\mathrm{P}$ mean in the soil in the bait tube ranges from $60.67 \mathrm{mg} \mathrm{Kg}^{-1}$ - $194.48 \mathrm{mg} \mathrm{Kg}^{-1}$ and considered in the high to a very high level in terms of soil fertility (Siswanto 2006). Buckman and Brady (1960) stated that P nutrients' need was absolute because plant growth depends on the amount of $\mathrm{P}$ availability in the soil with its role in root growth, stem, cell division, and seed ripening. The high P-value in the tube with a bait composition of 60\%: $0 \%: 40 \%, 0 \%$ : $0 \%$ : $100 \%$, and $60 \%: 20 \%: 20 \%$ is due to the higher values of soil $\mathrm{pH}$ in the surrounding and other compositions. According to Buckman and Brady (1960), P nutrients' availability is optimal at $\mathrm{pH} 6$ to $\mathrm{pH}<8$. The $\mathrm{P}$-solubility is influenced by $\mathrm{pH}$ at 6-7 when it is $<6$, enabling it to bond with $\mathrm{Fe}$ and $\mathrm{Al}$ (Mallarino 2000). $\mathrm{P}$ is the second essential macro element needed by plants after nitrogen, which functions in cell division, albumin formation, flower, fruit, and seed formation, accelerates ripening and strengthens stems, therefore they do not collapse easily.

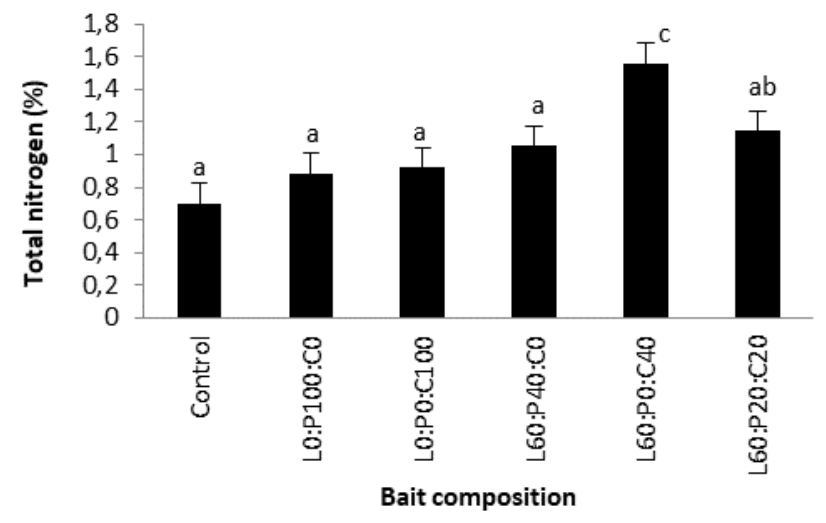

Figure 3. Total Nitrogen content at various bait compositions. Note: Caption see in Figure 1. Columns with a different letter differ significantly at a $95 \%$ confidence level

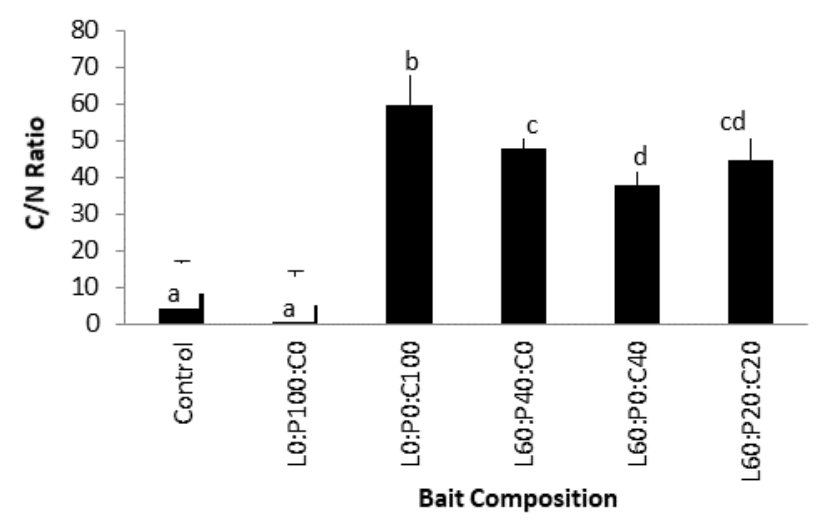

Figure 4. $\mathrm{C} / \mathrm{N}$ Ratio at various bait compositions. Caption see in Figure 1. Columns with different letters differ significantly at a $99 \%$ confidence level

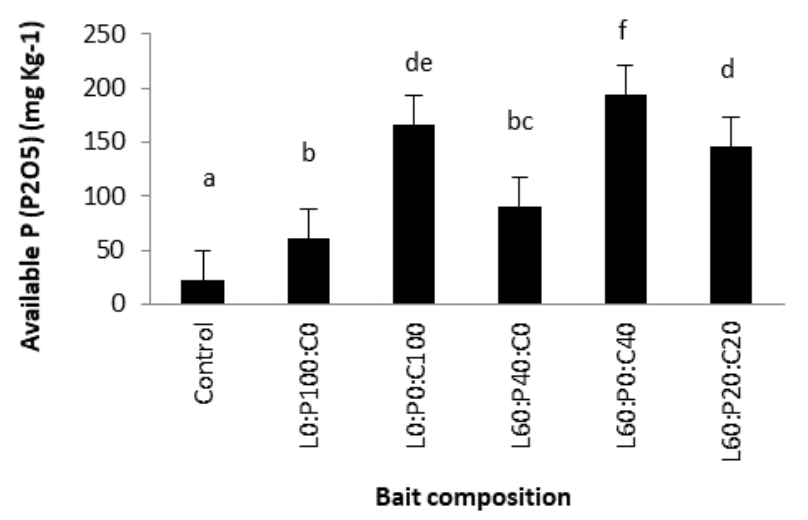

Figure 5. Available $\mathrm{P}\left(\mathrm{P}_{2} \mathrm{O}_{5}\right)$ at various bait compositions. Caption see in Figure 1. Columns with different letters differ significantly at the $99 \%$ confidence level 


\section{Cation Exchange Capacity (CEC)}

The lowest CEC mean was recorded on the soil around the nest and bait without eucalyptus leaves and cardboard with a value of $19.88 \pm 1.63 \mathrm{cmol} \mathrm{kg}^{-1}$ and $20.76 \pm 2.5$ $\mathrm{cmol} \mathrm{kg}^{-1}$. Meanwhile, the highest CEC was on the soil in tubes with bait made from a mixture of eucalyptus leaves and cardboard with $126.32 \pm 15.28 \mathrm{cmol} \mathrm{kg}^{-1}$ as shown in Figure 6.

There was a significant difference in CEC between the surrounding soil and those in the bait tube (Tukey's test: $\mathrm{P}$ $<0.01)$. The results of this study are similar to Deke et al. (2016) research using the same analysis of termite nests and surrounding soil. However, the CEC rate in cardboard baits or a mixture of eucalyptus leaves and cardboard is very high. This is related to the soil $\mathrm{pH}$ contained in each tube, with the High CEC due to the increase in soil $\mathrm{pH}$ in the tube. Meanwhile, according to Buckman and Brady (1960), the availability of CEC is optimal at soil pH 6 to $<8$. Soils with high CEC are able to absorb and provide nutrients better than those below.

\section{Potassium (K) content}

The average $\mathrm{K}$ content of $7.77 \pm 0.3 \mathrm{cmol} \mathrm{kg}^{-1}$ in the soil of bait tube with eucalyptus and cardboard is significantly different from the surrounding soil at $0.44 \pm$ $0.08 \mathrm{cmol} \mathrm{kg}^{-1}$ (Tukey's test: $\mathrm{P}<0.01$ ) as shown in Figure 7.

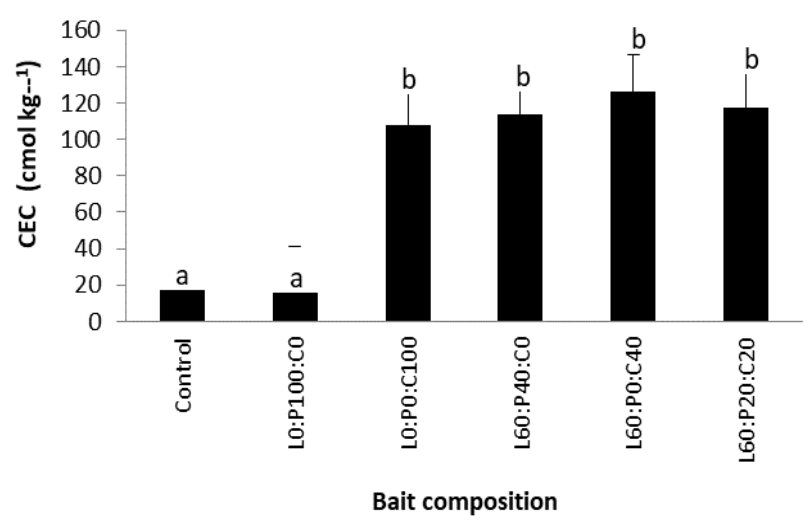

Figure 6. Cation exchange capacity (CEC) at various bait compositions. Note: Caption see in Figure 1. Columns with different letters differ significantly at $99 \%$ confidence level

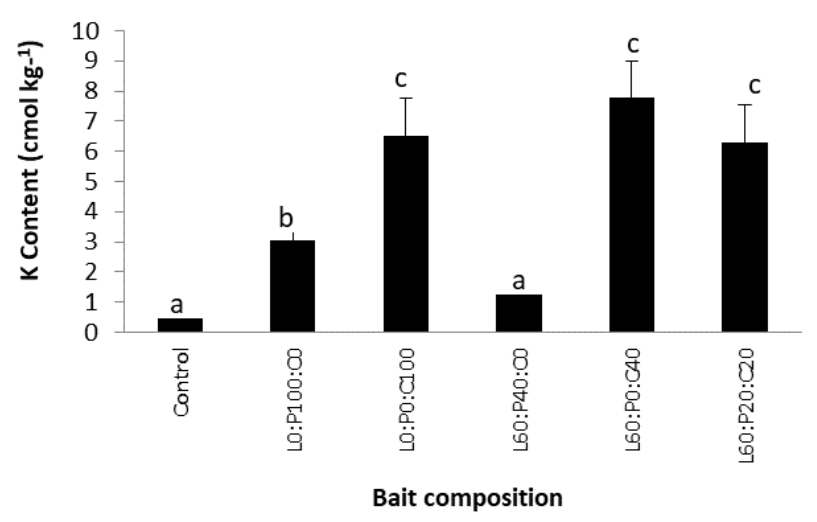

Figure 7. K Content at various bait compositions. Note: Caption see in Figure 1. Columns with different letters differ significantly at a $99 \%$ confidence level
Potassium is the third nutrient needed by plants after $\mathrm{N}$ and $\mathrm{P}$ because it plays an important role during photosynthesis, as well as in the formation of carbohydrates and proteins (Sudaryono 2009). The results of this study are in line with the analysis of $\mathrm{K}$ content in termite nests and surrounding soil carried out in Minna, Nigeria (Afolabi et al. 2014), Central Uganda (Apori et al. 2020a), Miyo and Yabello District of Borana Zone, Southern Ethiopia (Deke et al. 2016).

This study demonstrated that characteristics of biogenic structure resulted from the bait by the activities of subterranean termite were varied according to the composition of bait ingredient. The activities of termites allow change in the biogenic structure such as higher $\mathrm{pH}$, higher C-organic content, higher total nitrogen, higher available Phosphorus, higher CEC, and higher potassium content compared to the surrounding soil. The termite's biogenic product resulted from bait with the composition of 60 eucalyptus leaves, and 40 cardboard was observed to be the most favored composition by termites due to its high biogenic structure. The termite's biogenic product in bait composition of eucalyptus leaves 60 and cardboard 40 increased $\mathrm{pH}, \mathrm{C}$-organic content, total Nitrogen, available Phosphorus, CEC, and Potassium value more than $100 \%$.

The characteristic of biogenic products in this study will support the increase of soil fertility since termite's activity on bait composition change the soil chemical properties. However, how this change to the soil on a real scale needs to be further investigated.

\section{Termite species contributing in enhance soil chemical}

Three species of subterranean termites contribute to enhancing soil chemicals at the study site, i.e., Coptotermes sp., Schedorhinotermes sp., and Termes sp. (Figure 8). Species of Schedorhinotermes sp. was the most frequently found in bait tubes. Schedorhinotermes sp. belongs to subfamily Rhinotermitinae widely distributed in the tropical region (Nandika et al. 2015). The rest species, Coptotermes sp. (subfamily Coptotermitinae) and Termes sp. (subfamily Termitinae) were found in several bait tubes. Coptotermes sp. and Schedorhinotermes sp. found in bait tube in this research were also find in tropical forest in West Kalimantan (Indrayani and Yoshimura 2011) nor in buildings in Pontianak, West Kalimantan (Indrayani et al. 2017a).

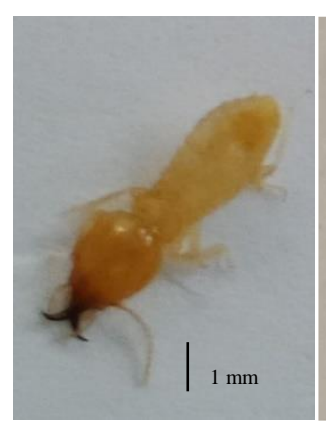

A

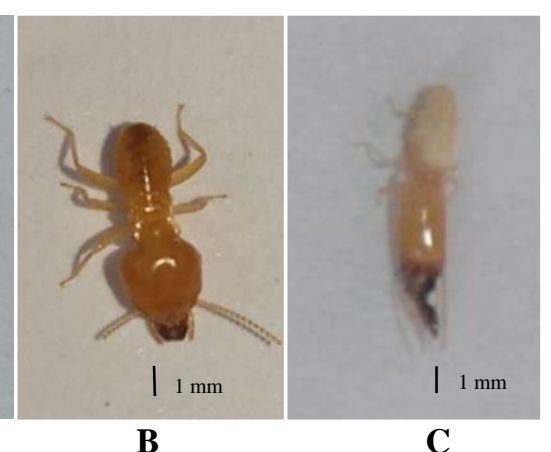

C
Figure 8. Subterranean termites contributing in enhance soil chemical: A. Coptotermes sp., B. Schedorhinotermes sp., C. Pericapritermes sp. 
In conclusion, this study highlights the use of mixture formulation of eucalyptus leaves, cardboard, and paper potentially used as termites' bait. The activity of termites significantly affects soil chemical properties and potentially improves land productivity. Furthermore, their activities increase soil $\mathrm{pH}, \mathrm{C}$-Organic content, Potassium content, total Nitrogen, available Phosphorous, and Cation Exchange Capacity by more than $100 \%$. Termite species contributing to enhancing soil chemicals in Arboretum of the Faculty of Forestry, Tanjungpura University were Coptotermes sp., Schedorhinotermes sp., and Termes sp. The most frequently found subterranean termite species in the study site was Schedorhinotermes sp. The composition of the bait favored by termites is $60 \%$ leaves and $40 \%$ cardboard.

\section{ACKNOWLEDGEMENTS}

The authors thank Director-General of Higher Education, Indonesian Ministry of Education and Culture for funding our research in 2020. Thanks also to students supported in this study.

\section{REFERENCES}

Apori SO, Murongo M, Hanyabui E, Atiah K, Byalebeka J. 2020a Potential of termite mound and its surrounding soil as soil amendments in smallholder farms in Central Uganda. BMC Res Note (13). DOI: 10.1186/s13104-020-05236-6.

Apori SO, Murongo M, Hanyabui E, Muli GK, Wamuyu B. 2020b. Role of military termites (Pseudocanthotermes militaris) in improving soil productivity in tropical agroecosystems. Ann Res Rev Biol 35(5):14 19. DOI: $10.9734 / \mathrm{arrb} / 2020 / \mathrm{v} 35 \mathrm{i} 530221$.

Afolabi SG, Ezenwa MIS, Dauda A. 2014. Physical and chemical characteristics of mound materials and surrounding soils of different habitats of two species in Minna, Nigeria. Prod Agric Technol 10 (2) 186-192.

Black HJJ, Okwakol MJN. 1997. Agricultural intensification, soil biodiversity and agroecosystem function in the tropics: the role of termites. Appl Soil Ecol 6(1):37-53. DOI: 10.1016/S09291393(96)00153-9.

Bera D, Bera S, DasChatterjee N. 2020. Termite mound soil properties in West Bengal, India. Geoderma Reg 22: e00293. DOI: 10.1016/j.geodrs.2020.e00293.

BAPEDA Kota Pontianak. 2018. Geographical and Demographic Conditions of Pontianak City. BAPPEDA, Pontianak. [Indonesian]

Buckman HO. Brady NC. 1960. The Nature and Properties of Soils, 6th ed. The Macmillan Co., New York.

Deke AL, Adugna WT, Fite AT. 2016. Soil physic-chemical properties in termite mounds and adjacent control soil in Miyo and Yabello Districts of Borana Zone, Southern Ethiopia. Am J Agr For 4 (4): 6974. DOI: 10.11648/j.ajaf.20160404.11.
Darlington JPE, Dransfield RD. 1987. Size relationships in nest populations and mount parameters in the termite Macrotermes michaelseni in Kenya. Insects Soc 34: 165-180.

Indrayani Y, Yoshimura T. 2011. Diversity of termite species in West Kalimantan. Proceeding of The $3^{\text {rd }}$ International Symposium of Indonesian Wood Research Society (IWORS). Gadjah Mada University, Yogyakarta, 3-4 November 2011.

Indrayani Y, Muin M, Yoshimura T. 2016. Crude extracts of two different leaf plant species and their responses against subterranean termite Coptotermes formosanus. Nusantara Biosci 8 (2): 226-231. DOI: 10.13057/nusbiosci/n080215

Indrayani Y, Takematsu Y, Yoshimura T. 2017a. Diversity and distribution of termites in buildings in Pontianak, West Kalimantan, $\begin{array}{llll}\text { Indonesia. } & \text { Biodiversitas } 18 \text { (3):954-957. DOI: }\end{array}$ 10.13057/biodiv/d180312.

Indrayani Y, Musrizal M, Yoshimura T. 2017b. Diversity of tropical plants and their attractant properties for subterranean termite Coptotermes curvignathus. Biodiversitas 18 (4): 1353-1357. DOI: 10.13057/biodiv/d180410.

Indrayani Y, M Muin, C Adilla, Yoshimura T. 2018. Attractiveness of subterranean termite Coptotermes formosanus to plant leaf extracts. Biodiversitas 19 (3): 1176-1180. DOI: 10.13057/biodiv/d190343.

Jouquet P, Chaudhary E, Kumar ARV. 2018. Sustainable use of termite activity in agro-ecosystems with reference to earthworms. A review. Agron Sustain Dev 38: 3. DOI: 10.1007/s 13593-017-0483-1.

Li Y, Dong ZY, Pan DZ, Chen LH. 2017. Effect of termite on soil pH and its application for termite control in Zhejiang Province, China. $\begin{array}{lllll}\text { Sociobiology } & 64 & (3): & 317-326 . & \text { DOI: }\end{array}$ 10.13102/sociobiology.v64i3.1674.

Lavelle P. 1997. Faunal activities and soil: Adaptive strategies that determine ecosystem function. Adv Ecol Res 27: 93-132.

Muin M, Arif A, Nuraeni S, Zohra WOF. 2015. Bait formulation from the mixture of degraded wood and waste paper to termite control. J Wood Trop Technol 13 (1):61-69. [Indonesian]

Muin M, Arif A. 2017. Conversion of waste paper-based bait formulation for biogenic production by termites in tropical land. J Solid Waste Technol Manag 43 (1):75-81.

Mallarino A. 2000. Soil Testing and Available Phosphorus. Integrated Corp Management News. Iowa State University, Ames, IO.

Pearce MJ. 1997. Termites: Biology and Pest Management. CAB International. New York.

Priya V, Lokesh M, Kesavan D, Komathi G, Naveena S. 2017. Evaluating the perfect carbon: nitrogen $(\mathrm{C}: \mathrm{N})$ ratio for decomposing compost. Intl Res J Eng Technol 4 (9): 1144 -1147.

Sholikhah SM, Wijayati N, Supartono, Suhartono. 2018. Production of bioethanol from used HVS paper through hydrolysis of oyster mushroom cellulase enzymes. Indonesian J Chem Sci 7(1):11-16. [Indonesian]

Siswanto. 2006. Evaluasi Sumberdaya Lahan. Penerbit UPN Press, Surabaya. [Indonesian]

Sudaryono. 2009. Ultisol Soil Fertility Level in Sangatta Coal Mining Land, East Kalimantan. Jurnal Teknologi Lingkungan, 10 (3): 331346. [Indonesian]

Syahfitri MM. 2008. Spectrophotometric Analysis of nutrients in palm oil leaves at the Research Center Kelapa Sawit (PPKS), Medan. [Hon. Thesis]. Universitas Sumatera Utara, Medan. [Indonesian]

Whiteford WG, Eldridge DJ. 2013. Effects of ants and termites on soil and geomorphological processes. In: Shroder JF (ed). Treatise on Geomorphology 12: 281-292. 